\title{
DIVERSITY OF SECONDARY EDUCATIONAL CURRICULA IN ESTABLISHMENTS OF GENERAL SECONDARY EDUCATION IN LATVIA
}

\author{
Valdis Krastins \\ Riga Secondary School No 93, Latvia \\ Vairis Laudams \\ Riga Teacher Training and Educational Academy, Latvia
}

\begin{abstract}
Within recent years significant changes have taken place in educational management as regards the development of democracy, decentralization of its management accentuating the importance of professional as well as effective management of schools. Aim of the Study. The aim of the research is to analyse several theories and the former practice of creation of educational curricula in general secondary education in Latvia. Materials and methods. The authors' of the article analyse the legal and educational management aspects in developing a general education curriculum in accordance with the Normative Guidelines and Acts of the Ministry of Education and Science to accentuate educators' as well as educational establishments' autonomy to develop education curricula, licensing as well as their implementation in practice. The analysis of the structure of the curricula at general education establishments is based on the comparative approach; also, the interpretation of the obtained results is carried out. Results. Development of educational curricula requires a specific outlook of regularities which focuses on the development of pupils' personality and community needs for a qualitative as well as appropriate knowledge. Scientists of educational management such as D.Pratt, J. Eglitis, G. Haydon in their research work deal with scientific grounds of the essence, development and innovation in the creative process of education curricula that are vitally important in the current circumstances in Latvia when schools balance each pupil, their parents', municipalities and the State order for education promoting each youngsters' career development in order to continue studies on a higher level of educating, foster their effective penetration into the labour market enhanced by availability of appropriate schools' technical as well as financial resources.

The authors explore school experience in developing general secondary education curricula as well as analyse their correlation with the sample education curricula.

The research reveals that schools develop general secondary education curricula creatively, highly evaluating professionalism, the significance of further educational development, pupils' requirements for a larger amount of lessons in certain subjects as well as the demands of the State Education Standard. Educational establishments carry out independently a vitally important job of planning; moreover, they add/supplement the offered samples of educational curricula by Ministry of Education and Science with new study subjects as well as suggest certain changes in the number of lessons in several study subjects.
\end{abstract}

Key words: educational management, general education, educational curriculum, school autonomy.

\section{Introduction}

Lately noticeable changes have taken place in educational management, i.e., further developmental trends of democracy, decentralisation of management as well as the emphasis on the significance of professionalism and efficiency in school management. Since 1991 school independence and autonomy in developmental planning of an educational establishment have increased greatly, also, in developing study curricula shouldering responsibility for the choice of educational services as well as enhancing educational quality. Legislation of Latvian education as 
well as Normative Acts promote the efficiency of school management and the development of democratization.

\begin{abstract}
Aim of the Work
The aim of the work is to analyse the theory of development of educational curricula and to explore the former practice of developing educational curricula in general secondary education in Latvia.
\end{abstract}

\title{
Materials and methods
}

The authors of the article analyse legal as well as educational management aspects of developing general education curricula in accordance with Normative Acts of Latvian Education and Regulations by the Ministry of Education and Science accentuating educators' and educational establishment independence to create, to license as well to implement education curricula in real life. The analysed structure of general secondary education curricula is compared with the educational curriculum samples by Ministry of Education and Science; also, the obtained results are interpreted.

In the plan of National Economic Development within the period of 2007-2013 the idea of knowledge is highlighted as the main resource of economic growth during the economic crisis. It explains why tasks in education as a branch of national economy are directed to a much higher level of educational quality expanding the choice of properly-developed education curricula balancing it with the state's sustainable development and its implementation:

1) To acquire qualitative general knowledge and proper skills, including nature studies, environmental studies and mathematics, to improve the choice of study context, methodology as well as the assessment system of pupils' study accomplishments in general basic education and secondary education.

2) To insist on the implementation of compulsory basic education and a gradual transition to compulsory secondary education (secondary general, secondary professional). To carry out preventive work with slow and less talented children and their parents to reach the acquisition level of basic education and secondary education (...) ( National Developmental Plan 2007-2013; 2007, 14).

These tasks directly point out the school responsibility for developing education curricula, proper planning of the resources of the educational establishment,exploration of community wishes and needs and the offer of an appropriate educational service. It is worth to note that the envisaged tasks in the National Developmental Plan should be treated with a developmental perspective, thus ensuring a sustainable development of the community in Latvia. It means that educational management tasks should be planned as well as solved accordingly.

A well known educational management expert in Latvia Janis Eglitis, Doctor of economic sciences in his article 'Education for knowledge of economics' stresses that 'educational system impacts the state's future therefore the scenarios of the development in Latvia have to be assessed in the context of the current educational system and the ongoing processes in it. In general the field of education is conservative, radical changes hardly ever occur in it; moreover, an immediate, effective solution of the existing problems, performing a few improvements in separate segments of the educational system are next to impossible and good for nothing'(Eglītis,2007, 142). It can be concluded that a solution might be expected in the long run notwithstanding the pre-condition that 
the state is within economic crisis. Definitely, educational management competence is bound to affect the current situation and its needs, i.e., the suitability of educational curricula to the pupils' as well as society's future needs and interests/ wishes.

D. Pratt in his articles on education programmes and humans well-being remarks that the chief task of the authors' of an education curriculum is to define educational priorities, i. e., decision-making, i.e., what is of great importance to learn so that it is worth teaching. Hypothesising this idea, the accounting point is the idea of a human's well-being' (Prets,2000, 11). He asserts precisely that education curricula are envisaged not only for the present but for the future as well therefore the authors of the curricula should be well-aware of forthcoming social trends and IT perspectives. Well-acquired skills in order to design an education curriculum is both a kind of art as well as science that fosters any educator's professional development and growth. Accordingly, higher educational establishments in their teacher training curricula should include a course of planning and modelling a school study process.

The dictionary of pedagogical terms associates the essence of educational curricula with a particular educational offer of a certain school, clarifying that it is a document 'which in accordance with the educational level, type, target audience and State Education Standard as well as Normative Acts, determines (...) the content of the offered education courses, pre-conditions of the learning process and their implementation grounded on the exploration of local needs as well as local trends and possible changes in the community '(Pedagoğijas terminu skaidrojošā vārdnīca, 2000, 74). It can be concluded that the analysis of local conditions and situation matters greatly in order to design school study curricula envisaging their development and suitability to the demands in everchanging labour market and the requirements of higher educational establishments.

Act on Education in the Republic of Latvia as well as General Education Rule regulates the development of education curricula, their structure, educators' participation in the creative process. For instance, Paragraph 17 of General Education Act declares that the aims and tasks of the educational curriculum must be included; also, content of education, the schedule of implementation of the study curriculum, requirements of the former educational background and the assessment criteria as well as the procedure, the evaluation of the required staff, financial means and material means in order to implement the education curriculum must be assessed and grounded (Act on Education, 1999, 24).

Ministry of Education and Science (IZM) in accordance with Education Act Paragraph 5, point 1 has confirmed competencies in the Directive \# 354 on August 24, 2009 of general secondary education curricula samples:

1.1. General secondary education ( comprehensive) sample of the curricula (education programme code 31011011), (...);

1.2. General secondary education ( humanitarian and social sciences )sample of curriculum (education code 31012011), (...);

1.3. General secondary education( mathematics, nature studiesand IT)sample of curriculum (education code 31013011), (...);

1.4. General secondary education vocationnally-oriented sample of curriculum (education code 31014011$),(\ldots)$;

1.5. General secondary education ( comprehensive curriculum for minorities)sample of curriculum (education code 31011021 ), (...);

1.6. General secondary education ( humanities and social sciences for minorities)sample of curriculum (education code 31012021), (...); 
1.7. General secondary education (mathematics, nature studies and IT for minorities) sample of curriculum (education code 31013021), (attachment 7)

1.8. General secondary education (vocationnally - oriented for minorities)sample of curriculum (education code of the curriculum 31014021), (attachment 8)

( Directives/guidelines of Ministry of Education and Science Directive 354 'On the confirmation of the sample curricula for general secondary education',2009,1).

Schools of general secondary education can make a 4-direction education curricula; all of them contain 8 compulsory/ core subjects. Each direction according to its essence, may include 3 to 6 compulsory study subjects. Any school, implementing their rights to democracy and autonomy, can offer optional study subjects in the range of $10-15 \%$ of the study sessions or to specialise in one of the compulsory subjects during the study period.General secondary education curricula of a particular direction can be combined with the education curriculum for minorities including the mother-tongue of minorities with their identity as well as study content associated with their integration into Latvian community.

In the manual 'Educational Psychology for Canadian Teachers' the authors highlight the idea that 'the schools are very important agents in the socialization of children. However, much of the school behaviour and many of the values and attitudes learned at school are not represented in formal statements of curriculum objectives" (Bowd A., McDougall D., Yewchuk C., 1994, 92). This approves the topicality of creating a thorough education curriculum so that it focuses on the most crucial, realistic and meaningful issues.

Graham Haydon in his book 'Values for Educational Leadership' emphasises that there is a room for differences of opinions about the desirability of having distinct parts of the curriculum to address moral and political aims. Some people would argue that such aims are better addressed simply through the ethos of the school and the example set by teachers. But anyone reflecting on how such aims are best addressed - and school leaders can hardly avoid such reflection - needs to get clearer on just what the aims are. It is easy to say that the aim is to produce good people and good citizens, but there is room for many interpretations of what this means (Haydon, 2007, 34).

It means that setting up aims in education curricula is a decisive task in educational management. Obviously, not only the school resources, traditions, insight into the needs of local community impact the development of study curricula and developmental dynamics.

The analysis of literature confirms the viewpoint that the documents about educational management and sustainable development of the state associate the future of Latvia with a highly qualitative general education that satisfies society-related needs. The autonomy of educational establishments linked with developing education curricula has greatly increased; likewise, the exploration of community needs and instilling meaningful values for the community during the teaching-learning process, in other words, the responsibility for educational quality depends on educational management in schools on a daily basis.

In order to explore the current situation in Latvia a research was carried out based on the information available at the State Service of Education Quality about the licenced general secondary education (GSC) curricula.

In accordance with the research data it can be concluded that schools in Latvia implement more than a 1000 general secondary education curricula ( excluding part-time and distance learning curricula). The largest number of the licenced curricula are general secondary education curricula whereas the least licenced ones are general secondary education vocationally-oriented curricula (see chart 1). 


\section{Chart 1. From 2001 to 2009 division of licenced education curricula according to directions}

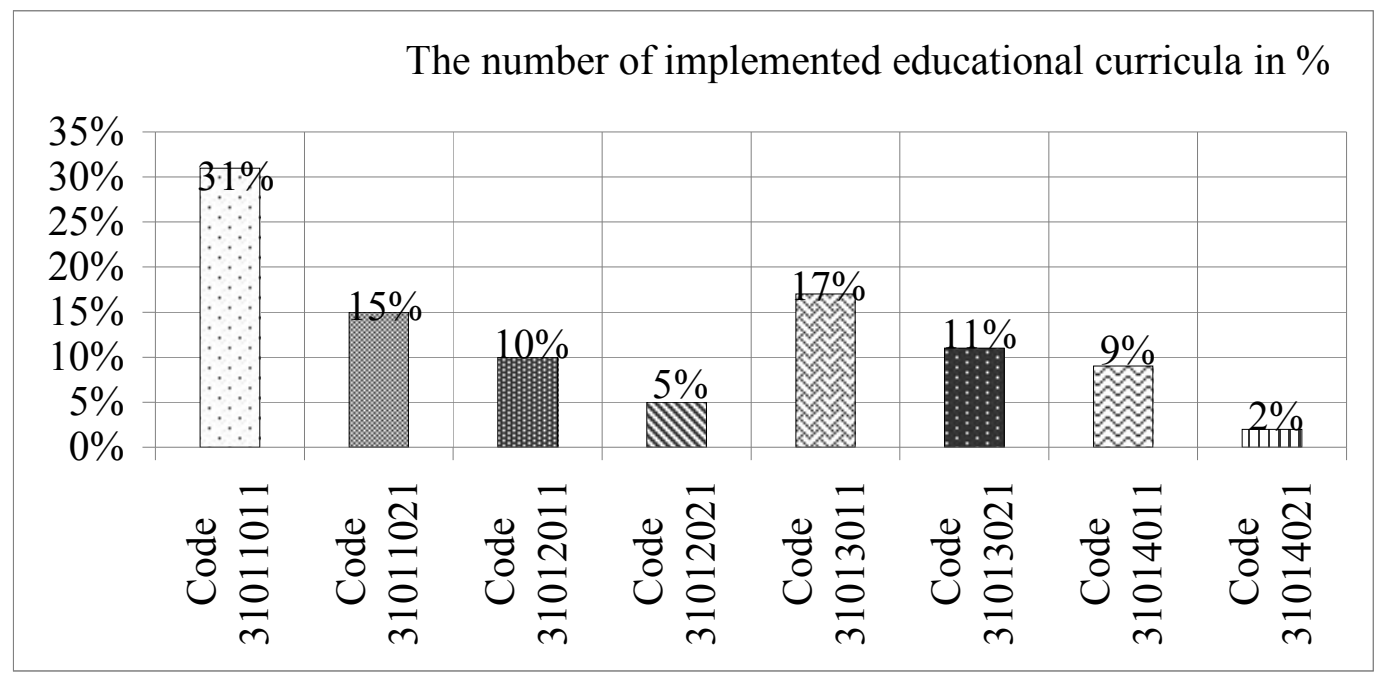

These data reveal that schools mainly implement general secondary education: comprehensive and mathematics, nature studies and IT direction/branches of curricula.

From July 1st, 2009 to February 1st, 2010168 general secondary education curricula have been licenced (excluding part-time and distance learning curricula), 39 (23\%) of the curricula are licenced in accordance with the sample education curricula by Ministry of Education and Science. As it can be seen in Table 1, the ongoing trend to implement general secondary education comprehensive and mathematics, nature studies as well as IT direction/branch of the curricula prevail. Comparatively few schools make use of licencing general secondary education curricula in accordance with the confirmed sample education curricula by the Ministry of Education and Science.

Table 1. Division of licenced general secondary education curricula according to branches (July 1st,2009 to February 1st,2010).

\begin{tabular}{|c|c|c|c|}
\hline $\begin{array}{c}\text { Educational } \\
\text { programme }\end{array}$ & $\begin{array}{c}\text { Licenced according } \\
\text { to sample of } \\
\text { Ministry } \%\end{array}$ & $\begin{array}{c}\text { Licenced-original } \\
\%\end{array}$ & $\begin{array}{c}\text { Total number of licenced } \\
\text { educational programmes }\end{array}$ \\
\hline 31011011 & 17 & 83 & 74 \\
\hline 31012011 & 14 & 86 & 18 \\
\hline 31013011 & 8 & 92 & 28 \\
\hline 31014011 & 32 & 68 & 22 \\
\hline 31011021 & 0 & 0 & 0 \\
\hline 31012021 & 0 & 100 & 12 \\
\hline 31013021 & 0 & 100 & 2 \\
\hline 31014021 & 17 & 83 & \\
\hline
\end{tabular}

The analysis of Table 1 and 2 illustrate precisely that comparatively a larger number of licenced programmes in accordance with the confirmed samples by the Ministry of Education and Science are general basic education, pre-school as well as specialised basic education curricula: 
Table 2. Licenced education curricula(July 1st, 2009-February 1st, 2010).

\begin{tabular}{|c|c|c|}
\hline Educational curricula & $\begin{array}{c}\text { Licenced according to the } \\
\text { sample of Ministry of } \\
\text { Education and Science \% }\end{array}$ & $\begin{array}{c}\text { The total number of } \\
\text { licenced education } \\
\text { curriculum }\end{array}$ \\
\hline General Basic Education curriculum & 77 & 88 \\
\hline Special Basic Education curriculum & 89 & 84 \\
\hline Pre-school Education curriculum & 80 & 90 \\
\hline
\end{tabular}

After analysing the content of the school original education curricula, it can be concluded that the most crucial difference between school original education curricula from the sample curricula by the Ministry of Education and Science is the number of the study subjects and the number of lessons as well. School original education curricula tend to plan a larger number of study subjects in most education curricula than the determined ones in the sample curricula by the Ministry of Education and Science. For instance,general secondary education of comprehensive direction licenced curricula (code 31011011) (see Table 2).

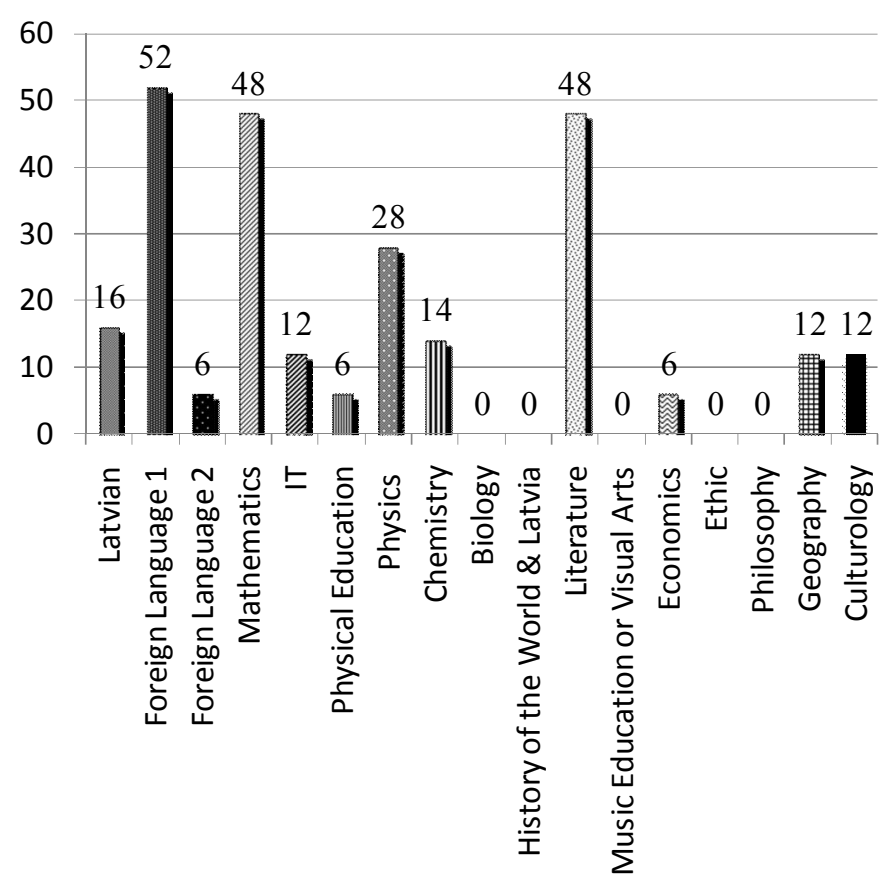

Bar chart 1. The number in \% of general secondary education of comprehensive direction (code 31011011) licenced curricula that exceed the number of study subjects and the number of lessons by the Ministry of Education and Science is the following. 


\section{The percentage of the number of education curricula \%}

It must be pointed out that the significant differences in the number of lessons if compared with the sample education curricula by the Ministry of Education and Science are the foreign language 1, mathematics and literature. At the same time it points to the necessity to revise the number of lessons of specific study subjects in the sample curriculum set by the Ministry of Education and Science to promote appropriate acquisition of the study subject according to the Standard.

It is obvious that schools highly appreciate the quality of education, keep enhancing the efficiency of the study process as well as implement study resources appropriately.

\section{Conclusions}

To develop a general education curriculum is a crucial task for high-rank education authorities. Legislation regarding education in Latvia regulates the developmental order of education curricula, determines their core as well as optional content. It can be taken as granted that educational establishments, the school administration as well as the educators' staff should take part in developing an education curriculum. D.Pratt, J.Eglitis, G.Haydon associate the development of education curricula and the content with a thorough insight into the future. The school administrative staff and educators should be well - aware of the future developments internationally as well as should have the necessary skills to prospect the social and technical changes locally while developing the structure and the content of the education curriculum.

The research outlines that schools creatively develop education curricula, estimate the pedagogical staff's professionalism, their further education, pupils' interests and the necessity for a larger number of lessons in specific study subjects as well as respect the requirements of the State Education Standard.Schools independently, i.e.,on their own initiative, carry out a significant developmental planning by expanding the offered curricula samples by Ministry of Education and Science. As a result, secondary education comprehensive schools are planning a larger number of lessons in specific study subjects in the comprehensive branch licenced curricula. It is necessary to reestimate the set number of lessons in specific subjects in the sample in the Ministry of Education in order to facilitate students to master them in accordance with the Standard in specific subjects as the school practice reveals that in order to uncover the foreign language 1, mathematics and literature a larger number of lessons is being planned.It must be stressed that school intentions are to optimise the use of available resources in the study process in order to enhance the education quality.

\section{References}

Bowd A., McDougall, D.,Yewchuk, C. (1994). Educational Psychology for Canadian Teachers, Harcourt Brace, Canada, 566.

Izglītîbas likums. Vispārējās izglītības likums. Profesionālās izglīîibas likums.Augstskolu likums.Education Law. General Education Law. Vocational Education Law. (1999). Rīga, Latvijas republika, Izglītîbas un zinātnes ministrija, 64 .

Eglīitis J. (2007). Izglîtība zināšanu ekonomikai. 142-162. Izglìtība zināšanu sabiedrības attīstībai Latvijā. Zinātniski pētnieciskie raksti, 2 (13) [Education for Economics of Knowledge. Education for Development of Knowledgeable Society in Latvia]. Riga: Zinātne.

Haydon, G. (2007). Values of Educational Leadership. Sage Publications. 

Terms).

Pedagog̣ijas terminu skaidrojošā vārdnīca (2000). Riga: Zvaigzne ABC (Glossary of Pedagogics

Latvijas Republikas Izglīitības un zinātnes ministrijas rīkojums Nr.354 „Par vispārējās vidējās izglìtības programmu paraugu apstiprināšanu" Regulation of Ministry of Education and Science No 354

http://izm.izm.gov.lv/upload file/programmu\%20paraugi/IZMrik 354 vid\%20izgl\%20progr.doc,1: $\quad$ viewed 12.02.2010)

Received 10 January 2010; accepted 15 February 2010

\section{प $\quad$ Valdis Krastins}

Dr.paed., Riga Secondary School No 93, Andromedas Street, 7-87, Riga, Latvia.

Phone: +37129501283

E-mail: valdis.krastins@rpiva.lv

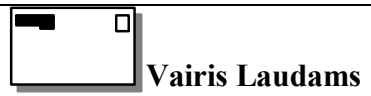

Lecturer Mg.sc.coc., Riga Teacher Training and Educational Management Academy, Latvia

Bērzu iela 8, Dobele, Latvija

Phone: +37129140154

E-mail: vairis.laudams@inbox.lv 